\title{
Yoğun Bakımda Akut Böbrek Yetmezliği Olan Yetişkin Olgu Sunumu
}

\author{
A Case Report of Acute Renal Failure in Intensive Care Unit
}

\section{Sevan Çetin ${ }^{1}$}

Geliş tarihi/Received: 04.02.2018 • Kabul tarihi/Accepted: 02.11.2018

\section{ÖZET}

Yoğun bakımda akut böbrek hasarı sağlığı tehdit eden, morbidite ve mortaliteyle ilişkili ciddi bir hastalıktır. Özellikle akut böbrek hasarı olan yoğun bakım hastalarında malnütrisyon, negatif klinik prognozla sonuçlanan önemli bir etmendir. Dolayısıyla nütrisyonel riski olan bu hastalarda nütrisyonel tedavi hastalığa, verilen tedaviye, komplikasyonlara, gereksinmelere ve demografik özelliklere uygun yapılmalıdır. Bu yazıda kardiyovasküler cerrahi yoğun bakımda akut böbrek yetmezliği gelişen bir olguda nütrisyonel tedavi ve yoğun bakımdan kliniğe ve taburculuğa geçiş süreci aktarılmıştır.

Anahtar kelimeler: Yoğun bakım, akut böbrek yetmezliği, parenteral beslenme, enteral beslenme

\begin{abstract}
Acute kidney injury in the intensive care unit (ICU) is a life-threatening serious disease that is associated with morbidity and mortality. Malnutrition is an important factor that results in a negative clinical prognosis, especially in ICU patients with acute renal injury. Therefore, nutritional therapy should be started in accordance with the disease, treatment, complications, requirements and demographic properties in these patients with nutritional risk. In this case report, nutritional therapy of acute renal failure in the ICU of cardiovascular surgery was discussed. The transition of patient from intensive care unit to the clinic and discharge was also presented.
\end{abstract}

Keywords: Intensive care, acute renal failure, parenteral nutrition, enteral nutrition

\section{Gíriş}

Tüm dünyada yoğun bakım hastalarında bir komplikasyon olarak gelişen akut böbrek hasarı, hastanede kalış süresi, sağlık harcamalarında artış ve mortaliteyle sonuçlanan ciddi bir sağlık sorunudur (1-3). Akut böbrek hasarı, saatler ve günler içerisinde böbreğin glomerular filtrasyon hızının azalması, elektrolit ve sivı homeostazının bozulmasıyla karakterize ve yaşamı tehdit eden bir hastalıktır (4). Akut böbrek hasarının yoğun bakım hastalarında görülme insidansı \%3-30, mortalite oranı \%36-90 arasında olduğu belirtilmektedir (2). Akut böbrek yetmezliği terimi, patolojiyi ve organ yetmezliğinin klinik seyrini daha iyi yansıtması nedeniyle günümüzde "akut böbrek hasarı" teriminin yerine kullanılmaktadır (5).

Akut böbrek hasarının oluşumuna etki eden risk etmenleri yaş, kalp yetmezliği, karaciğer yetmezliği, anemi, obstetrik kanama, sindirim hemorajisi, sepsis, şok, enfeksiyonlar, mekanik ventilasyon

1. İletişim/Correspondence: Türkiye Cumhuriyeti Sağlık Bakanlı̆̆ı Türkiye Yüksek İhtisas Eğitim ve Araştırma Hastanesi, Ankara, Türkiye • E-posta: sevan.cetin@gmail.com (i) https://orcid.org/0000-0002-3451-9834 
gereksinmesi, cerrahi, antibiyotikler ve non-steroidal antiinflamatuvar ilaçlar gibi nefrotoksik ajanlardır $(1,2)$. Bununla birlikte yatan hastalardaki kötü prognoz ve hastalığın iyatrojenik yapısı da hastalığın gelişimiyle ilişkilendirilmektedir (1).

Yoğun bakım hastaları arasında böbrek işlevlerini değerlendirmede birçok parametre kullanılmasına karşılık, yaygın kullanılan parametreler serum kreatinin ve idrar çıkışıdır (1). Sistatin C gibi küçük proteinler akut böbrek hasarının erken tanısında kullanılmaktadır $(2,6)$. Akut böbrek hasarı gelişen hastalarda hiperkalemi, metabolik asidoz, volüm yüklenmesi gelişebilmekte ve ciddi akut böbrek hasarı olan hastalarda renal replasman tedavisi gerekmektedir (7).

Akut böbrek hasarında nütrisyonel tedavi ile protein enerji kaybının engellenmesi, kas kütlesinin ve nütrisyonel durumun korunması, metabolik komplikasyonların önlenmesi, varsa bası yaralarının düzeltilmesi, immun sistemin desteklenmesi, inflamasyonun azaltılması, antioksidan kapasite ve endotel işlevin arttırılması ve mortalitenin azaltılmasinı hedeflenmektedir $(8,9)$.

\section{OLGU SUNUMU}

Olgu, daha önceden aort valf replasmanı (AVR) ve mitral valf replasmanı (MVR) cerrahisi ile iki sene sonra tekrar reMVR cerrahisi geçirmiş 58 yaşında erkek hastadır. Göğüs ağrısı nedeni ile acil servise başvuran hastada yapılan tetkikler sonucunda hareketi bozulmuş aort kapağı saptanmış, acil operasyona alınan hastaya kardiyopulmoner bypass ve reAVR ameliyatı yapılmıştır. Operasyondan entübe ve inotrop desteklerle çıkan hastanın tansiyonu 53/38 $\mathrm{mm} / \mathrm{Hg}$ olduğundan adrenalin başlanmıştır. Sağ göz refleksi zayıf, ayak uçları soğuk, siyanotik ve ajitasyonu olan hastanın senkronize aralıklı zorunlu ventilasyon desteği (SIMV) devam etmiş, uyanıklığı olan hastanın, kooperasyonu negatif olarak değerlendirilmiştir. Hastanın ejeksiyon fraksiyonu \%40 belirlenmiştir. Hastanın biyokimyasal bulgularından, kan glukozu $182 \mathrm{mg} / \mathrm{dL}$, kan üre azotu (BUN) $87 \mathrm{mg} / \mathrm{dL}$, serum kreatinin $1.50 \mathrm{mg} / \mathrm{dL}$, glomeruler filtrasyon hızı (eGFH) 48, serum albümin $3.4 \mathrm{~g} / \mathrm{dL}$, serum potasyum $2.76 \mathrm{mmol} / \mathrm{L}, \mathrm{C}$-reaktif protein $16.5 \mathrm{mg} / \mathrm{L}$ bulunmuştur. Post-operatif $3200 \mathrm{~mL}$ idrar çıkaran hastanın, bir sonraki gün $150 \mathrm{~mL}$ idrar çıkarması üzerine nefroloji konsültasyonu istenmiştir. Santral venöz basınç (CVP) +15 olan hastada sıvı retansiyonuna bağlı hipervolemi mevcut olduğu belirtilmiştir. Konsültasyon sonucu hastanın aldığı/çıkardığı sıvı miktarının +600 $\mathrm{mL}$ olarak ayarlanması, nefrotoksik ajanlardan kaçınılması, hastanın durumu stabil olunca diyaliz için tekrar danışılması önerilmiştir. Saatte $10 \mathrm{mg}$ Lasix infüzyonu başlanmış, ultrafiltrasyon (UF) için diyalize alınarak 3 saatte 2 L mayi çekilmiştir.

Entübasyonu devam eden hastaya post-operatif 2. günde nütrisyon ünitesinden konsültasyon istenmiştir. SIMV desteği devam eden hastanın santral kateteri (jugular ven) mevcuttur.

Hastanın beslenme durumunun değerlendirilmesi Nütrisyonel Risk Taraması (NRS 2002) ile yapılmıştır. Buna göre nütrisyon durumundaki bozulmanin değerlendirilmesinde beden kütle indeksi (BKI) 21.0 $\mathrm{kg} / \mathrm{m}^{2}$ bulunan hastanın entübe ve besin alımının olmaması (geçen haftaki besin alımı gereksinmelerin \%0-25’i) nedeniyle skor 3 olarak değerlendirilmiş, hastalığın şiddeti skor 3 kabul edilmiş ve toplam skorlama 6 bulunduğundan hastanın nütrisyonel risk altında olduğu ve nütrisyonel tedaviye başlanması gerektiği belirlenmiştir.

Nütrisyonel Risk Taraması 2002'de bulunan APACHE skorlaması yoğun bakım hastalarında "Akut Fizyoloji ve Kronik Sağlık Değerlendirmesi” (APACHE) mortalite hızının ve tedavi etkinliğinin değerlendirilmesinde kullanılan sistemlerinden biridir (10). Ayrıca kritik hastalarda nütrisyonel risk (The Nutrition Risk in the Critically Ill-NUTRIC Score) skoru, yoğun bakım hastalarında gelişen advers olayları ölçmek için ve beslenme tedavisini belirlemek için geliştirilmiş yardımcı sistemlerden birisidir (11). 
Hastanın yaşı 58 olup, süregelen vücut ağırlığı 55 $\mathrm{kg}$, boy uzunluğu $160 \mathrm{~cm}$ belirlenmiş ve hastanın BKİsi $21.0 \mathrm{~kg} / \mathrm{m}^{2}$ bulunmuştur. Ülkemizde 1-74 yaş grubundaki bireylerde BKİ referans değerleri için Ulusal Sağlık İstatistikleri Merkezi (National Center For Health Statistics) [NCHS] kullanılmaktadır (12). Hastaya parenteral yoldan nütrisyon tedavisine karar verilmiştir. Hastanın ateşi $36^{\circ} \mathrm{C}$, tansiyonu $104 / 45 \mathrm{~mm} /$ Hg olarak ölçülmüştür.

Hastanın enerji, protein ve diğer besin ögesi gereksinmelerini hesaplamak için akut böbrek hasarı olan hastaların tıbbi beslenme tedavisi önerileri için Amerika Birleşik Devletleri'nde Ulusal Böbrek Vakfı'nın Böbrek Hastalığı Sonuçları Kalite Girişimi (NKF/KDOQI / National Kidney Foundation Kidney Disease Outcomes Quality Initiative) kılavuzu, Avrupa Parenteral ve Enteral Nütrisyon Derneği (European Society for Parenteral and Enteral Nutrition / ESPEN), Amerika Parenteral ve Enteral Nutrisyon Derneği (American Society for Parenteral and Enteral Nutrition) (ASPEN) ve Yoğun Bakım Tıbbi Derneği (Society of Critical Care Medicine) (SCCM) kllavuzları kullanılmıştır (13-15). Hastanın enerji gereksinmesi ve gereksinmeyi artturan ilgili etmenler Tablo 1'de gösterilmiştir.

Tablo 1. Hastanin gereksinmeleri $(9,13)$

\begin{tabular}{|c|c|c|c|}
\hline Gereksinme & & & Toplam \\
\hline \multirow[t]{2}{*}{ Enerji } & Schofield formülü= & 1517 kkal/gün & \\
\hline & $25 \mathrm{kkal} / g u ̈ n=$ & 1375 kkal/gün & \\
\hline Fiziksel aktivite faktörü & $\% 10$ & & \\
\hline Travma faktörü & \%10 (post-op ilk 4 gün 0-10) & & \\
\hline \multirow[t]{2}{*}{ Ventilasyon faktörü } & $-\% 15$ & & \\
\hline & & & 1546 kkal/gün \\
\hline Protein & $1.2 \mathrm{~g} / \mathrm{kg} / \mathrm{gün}$ & & $66 \mathrm{~g}$ \\
\hline $\mathrm{NPE} / \mathrm{N}$ & $146 / 1$ & & \\
\hline $\mathrm{C} / \mathrm{N}$ & $171 / 1$ & & \\
\hline
\end{tabular}

C: Kalori Kkal: Kilokalori N: Azot NPE: Non-protein Enerji

Hastaya santral venöz yoldan verilmiş olan total parenteral nütrisyon (TPN) içeriği Tablo 2'de gösterilmiştir.

Tablo 2. Total parenteral beslenme solüsyon içeriği

\begin{tabular}{lll}
\hline İçerik & TPN 2. gün & TPN 3. gün \\
\hline \%10 Aminoasit & $495 \mathrm{~mL}$ & $660 \mathrm{~mL}$ \\
\%50 Dekstroz & $410 \mathrm{~mL}$ & $546 \mathrm{~mL}$ \\
\%20 Lipit & $262 \mathrm{~mL}$ & $349 \mathrm{~mL}$ \\
Vitamin & Tek doz & Tek doz \\
Eser element & Tek doz & Tek doz \\
Enerji & $1160 \mathrm{kkal} / \mathrm{gün}$ & $1546 \mathrm{kkal} / \mathrm{gün}$ \\
Toplam miktar & $1167 \mathrm{~mL}$ & $1555 \mathrm{~mL}$ \\
\hline
\end{tabular}

TPN: Total parenteral nütrisyon

Hastaya ilk gün için hazır üçü bir arada karışımlardan zeytinyağı ve soya yağı temelli $610 \mathrm{kkal} / 1000 \mathrm{~mL}$ ve 22 g protein içeren ürün kullanılmıştır. Eser element ve multivitamin desteği 1 flakon olacak şekilde üçü bir arada torbaya eklenmiştir.

Nütrisyon tedavisinin başlamasından 2 gün sonra ventilasyon cihazından ayrılmaya çalışılan hastanın, spontan solunumu desteklemeye yarayan "Duo Positive Airway Pressure (DuoPAP)" basınç moduna alınmasına karar verilmiş, ventilasyon gereksinmesi olmazsa, Rejim1 ile oralinin açılmasına karar verilmiştir.

İdrar çıkışı 50 mL/gün olan hastanın toplam mayi alımı $1500 \mathrm{~mL} / g u ̈ n$ ile sınırlandırılmış ve hemodiyalize (HD) alınan hastadan 2 L mayi çekilmiştir. Tekrar ventilasyon desteğine gerek duymayan ve oral alımı açllan hasta, yoğun bakımdan kliniğe nakledilmiş, oral alımı Rejim²’ye dönüştürülmüştür. Hastanın biyokimyasal parametreleri kan glukozu 119 mg/dL, 
kan üre azotu $164 \mathrm{mg} / \mathrm{dL}$, serum kreatinin $3.83 \mathrm{mg} / \mathrm{dL}$, total protein $6.1 \mathrm{~g} / \mathrm{dL}$, serum albümin $2.9 \mathrm{~g} / \mathrm{dL}$ olup, elektrolitleri normal referans değerler içerisinde çıkmıştır.

Total parenteral nütrisyonu kademeli olarak azaltılan hastanın günlük besin tüketiminde $500 \mathrm{kkal} /$ gün ve 10 g/gün protein tükettiği saptanmış ve bu nedenle $2 \times 1$ standart enteral formüla başlanmıştır. Toplam 5 gün parenteral tedavi alan hastanın TPN'si durdurulmuş, diyet ve oral enteral ürün ile beslenme tedavisine devam edilmiştir.

Yoğun bakımdan çıkışı sağlanan ve klinikte yatan hastaya, bulantı, iştahsızlık ve uykusuzluk nedeniyle psikiyatri konsültasyonu istenmiş, operasyondan 15 gün öncesine kadar kannobinoid ve alkol bağımlılığı olduğu saptanmıştır. Antidepresan ve antipsikotik tedavi başlanan hastanın idrar çıkışının da (genel sıvı dengesi 2200-2900 mL) normale dönmesi nedeniyle tekrar nefroloji konsültasyonu istenmiştir. İlaveten hastada plevral effüzyon saptanmış ve mayi alımı 1500 mL/gün ile sınırlandırılmıştır.

Oral alımı Rejim (kronik böbrek yetmezliği diyeti ile uyumlu) olan hastaya standart enteral ürünü tüketememesi nedeniyle böbrek hastalarma özel, elektroliti düşük, $2 \mathrm{kkal} / \mathrm{mL}$ - $500 \mathrm{~mL}$ olan oral enteral ürünü önerilmiştir (9).

Fiziksel hareketi ve besinlerin termik etkisiyle enerji gereksinmesi artan hastanın genel enerji ve protein gereksinmesi $2124 \mathrm{kkal} /$ gün ve $72 \mathrm{~g} / \mathrm{kg} / \mathrm{gün}$ hesaplanmış ancak besin tüketim kaydına göre 1128 kkal/gün ve 35 g/gün protein tükettiği belirlenmiştir. Hastanın oral enteral ürünün ise yarısını tükettiği kaydedilmiştir. Taburculuk öncesi biyokimyasal parametreleri kan glukozu 100 mg/dL, kan üre azotu $78 \mathrm{mg} / \mathrm{dL}$, serum kreatinin $1.03 \mathrm{mg} / \mathrm{dL}$, total protein $7.0 \mathrm{~g} / \mathrm{dL}$, serum albümin $2.8 \mathrm{~g} / \mathrm{dL}$ 'dir. Klinik diyetisyeni ile görüşülerek diyet modifikasyonu yapılan hastanın oral tüketimi artmış ve taburculuğu gerçekleşmiştir.

\section{TARTIŞMA}

Yoğun bakım hastalarında akut böbrek hasarı malnütrisyon ve malnütrisyonun klinik sonuçları için bir risk etmenidir (8). Bu hasta grubunda hastanede yatan hastalarda mortalitede bağımsız bir belirleyicidir (13). Hastanın gereksinmesi olan enerji gereksinmesinin tümü sağlansa dahi hiperkatabolik bir süreç yaşanmaktadır (5). Kılavuzlar ilk 48 saat içerisinde tüm hospitalize hastaların nütrisyonel yönden taranmasını özellikle de yoğun bakım hastalarında ayrintılı bir taramanın yapılmasını önermektedir $(14,15)$.

Yoğun bakım hastalarında oral alımın mümkün olmadığı durumlarda ilk 48 saat içerisinde öncelikle tercih edilen beslenme tedavisi yöntemi enteral beslenme olmalıdır (14). Bu olguda enteral beslenme, hastanın kısa içerisinde ekstübasyonu öngörüldüğünden istenmemiş, parenteral nütrisyon tedavisi başlanmıştır. Enerji harcanmasının belirlenmesinde altın standart indirek kalorimetre yöntemidir. Ancak indirekt kalorimetrenin mümkün olmadiğı durumlarda pulmoner arteriyel kateterden kullanılan VO2 tüketimi veya ventilatörden elde edilen VCO2 üretimi ile veya ağırlığa dayalı 20-25 kkal/ kg/gün gibi basit yöntemler, enerji gereksiniminin değerlendirilmesinde kullanılan tekniklerdendir (14). $\mathrm{Bu}$ olguda enerji gereksinmesinin hesaplanmasinda formülasyon ve ağırlığa dayalı pratik yöntemler kullanılmıştır. İlaveten yoğun bakım hastalarında hastalığın erken fazında enerji gereksinmesinin \%70'ni geçmeyecek şekilde beslenme tedavisi önerilmektedir (14). Bu olguda da enerji gereksinmesi kademeli bir şekilde arttırılmıştır.

Akut böbrek hasarında renal replasman tedavisinin önlenmesi veya gecikmesi amacıyla protein kısıtlaması önerilmemektedir. Non-katabolik, diyalize gereksinmesi olmayan akut böbrek hasarı olan hastalarda $0.8-1.0 \mathrm{~g} / \mathrm{kg} / \mathrm{gün}$ protein önerilirken, renal replasman tedavisi (RRT) alan hastalarda $1-1.5 \mathrm{~g} / \mathrm{kg} /$ gün ve sürekli RRT alan ve hiperkatabolik hastalarda en fazla $1.7 \mathrm{~g} / \mathrm{kg} /$ güne kadar protein önerilmektedir (13). Bu olguda orta derecedekatabolizma nedeniyle protein 
miktarı $1.2 \mathrm{~g} / \mathrm{kg} /$ gün protein verilmiştir. Uygulanan nütrisyonel tedavinin etkinliğinin izlenmesinde klinik bulgular, nütrisyonel parametreler, antropometrik ölçümler, fonksiyonel parametreler ve sıvı balans izlemleri kullanılmıştır (16). Bu olguda parenteral beslenme ile başlayan nütrisyonel tedavi, hastanın oral alımının açılmasıyla oral enteral ürün desteği ve diyet modifikasyonunu içeren multidisipliner bir ekip çalışmasıyla devam etmiştir. Hastaların beslenme tedavilerinde oral enteral ürün izlemi ve diyet modifikasyonu önem taşımakta ve hastayı motive edici bir etmen olarak karşımıza çıkmaktadır. Hastanın diyalizinin sonlandırılması, iştahının yerine gelmesi, biyokimyasal parametrelerinin başlangıca göre düzelmiş olması nütrisyonel desteğin etkinliğinin bir sonucudur.

Sonuç olarak, yoğun bakımda akut böbrek hasarı ağır klinik sonuçlar ve sağ kalımda azalmayla ilişkilendirilmektedir (2). Akut böbrek hasarı olan yoğun bakım hastalarında enteral ve parenteral beslenme bütüncül bir yaklaşım olarak kabul edilmeli, hastaya uygun yöntem aracılığıyla ile beslenmesine ait tedavi hedefleri gerçekleştirilmelidir.

Çıkar çatışması - Conflict of interest: Yazarlar çıkar çatışması olmadığını beyan ederler. - The authors declare that they have no conflict of interest.

\section{KAYNAKLAR}

1. Bellomo R, Ronco C, Metha LR, Asfar P, Boisramé-Helms J, Darmon M, et al. Acute kidney injury in the ICU: from injury to recovery: reports from the 5th Paris International Conference. Ann Intensive Care 2017;7:49.

2. Mahmood N, Rahman MF, Rahman MM, Shaid SMH, Siddiqui MMR. Acute kidney injury in patients of intensive care unit. AKKMMC J 2017;8(1):38-44.

3. Seller-Pérez G, Màs-Font $\mathrm{S}$, Pérez-Calvo $\mathrm{C}$, Villa-Díaz P, Celeya-López M, Herrera-Gutiérrez ME. Acute kidney injury: Renaldisease in the ICU. Med Intensiva 2016;40(6):374-82.
4. Shah RZ, Tunio AS, Arshad HM, Moazzam Z, Noorani K, Feroze MA, et al. Acute kidney injury recognition and management: A review of the literature and current evidence. Glob J Health Sci 2016;8(5):120-4.

5. Krenitsky J, Rosner HM, Parrish RC. Nutritional support for patientswith acute kidney injury: how much protein is enough or too much? Practical Gastro 2011;35(6): 2842.

6. Mohsenin V. Practical approach to detection and management of acute kidney injury in critacally ill patient. J Intensive Care 2017;5:57.

7. Moore KP, Hsu KR, Liu DK. Management of acute kidney injury: Core curriculum 2018. Am J Kidney Dis 2018;72(1):136-48.

8. Fiaccadori E, Regolisti G, Cabassi A. Specific nutritional problems in acute kidney injury, treated with nondialysis and dialytic modalities. NDT Plus 2010;3:1-7.

9. Cano NJM, Aparico M, Brunori G, Carrero JJ, Cianciaruso B, Fiaccadori E, et al. ESPEN guidelines on parenteral nutrition: Adult renal failure. Clin Nutr 2009;28(4):4014.

10. Geyik DF, Altun TG, Çıtak N, Ayazoğlu AT. Genel yoğun bakım ünitesinde APACHE II ve APACHE IV skorlama sistemlerinin karşılaştırılması. JARSS 2013;21(3):182-6.

11. What is the NUTRIC Score? Available at: https://www. criticalcarenutrition.com/resources/nutric-score Accessed January 19, 2019.

12. Pekcan G. Beslenme durumunun saptanması. In: Baysal A, editör. Diyet El Kitabı. 6. Baskı. Ankara: Hatipoğlu Yayınevi; 2011.s.67-143.

13. KDIGO Clinical Practice Guideline for Acute Kidney Injury. Glycemic control and nutritional support. Available at:http://www.kidney-international.org Accessed January 20, 2019.

14. Singer P, Blaser RA, Berger MM, Alhazzani W, Calder CP, Casaer PM, et al. ESPEN guideline on clinical nutrition in the intensive care unit. Clin Nutr.2019 Feb;38(1):48-79.

15. McClave AS, Taylor EB, Martindale GR, Warren MM, Johnson RD, Braunschweig C, et al. Guidelines for the provision and assessment of Nutrition support therapy in the adult critically ill patient: Society of Critical Care Medicine (SCCM) and American Society for Parenteral and Enteral Nutrition (A.S.P.E.N.). JPEN 2016;40(2):159211.

16. Allison S. Basics in clinical nutrition: Monitoring of nutritional support, clinical monitoring. e-SPEN 2009;4:229-30. 